\title{
USVL-380, a Zucchini yellow mosaic virus-resistant Watermelon Breeding Line
}

\author{
Amnon Levi ${ }^{1}$ and Kai-shu Ling \\ U.S. Department of Agriculture, Agricultural Research Service, U.S. \\ Vegetable Laboratory, 2700 Savannah Highway, Charleston, SC 29414
}

Additional index words. potyvirus, cucurbit, disease, resistance, ELISA, DNA marker, elongation factor

USVL-380 is a watermelon breeding line [Citrullus lanatus (Thunb.) Matsum. \& Nakai] with resistance to the Zucchini yellow mosaic virus-Florida strain (ZYMV-FL) (Provvidenti, 1991; Provvidenti et al., 1984). This new breeding line is homozygous for the recessive eukaryotic elongation factor eIF4E allele associated with ZYMV resistance, identified in United States Plant Introduction (PI) 595203 (Harris et al., 2009; Ling et al., 2009). This breeding line was developed at the USDA, ARS, U.S. Vegetable Laboratory, Charleston, SC.

\section{Origin}

Development of USVL-380 was initiated in 2009 with the observation that the eukaryotic elongation factor eIF4E allele of the watermelon PI 595203 is associated with ZYMV-FL resistance (Harris et al., 2009; Ling et al., 2009). The USVL-380 was developed through a breeding plan that initially involved the construction of an $\mathrm{F}_{2}$ population derived from a cross between the ZYMV-FLresistant PI 595203 (globular fruits with light green gray rind and white flesh with dense texture and slightly bitter taste and white seeds; Guner, 2004) and the highly susceptible heirloom watermelon cultivar New Hampshire Midget (Fig. 1). The phenotyping procedure for ZYMV resistance included stringent evaluation of disease symptoms for plants inoculated with ZYMV-FL in the greenhouse, an enzyme-linked immunosorbent assay (ELISA), and marker-assisted selection using two cleaved amplified polymorphic sequence (CAPS) markers of the eIF4E gene locus (CAPS1, CAPS2) and a sequenced characterized amplified region (SCAR) marker (designated as ZYRP) associated with ZYMV-FL resistance (Harris et al., 2009; Ling et al., 2009).

Young $\mathrm{F}_{2}$ plants (2-3 leaf stage) were inoculated two times with ZYMV-FL, at 1 week apart between the two inoculations. The plants were evaluated at the end of the third week after the first inoculation. Plants

Received for publication 18 July 2017. Accepted for publication 24 Aug. 2017.

${ }^{1}$ Corresponding author. E-mail: amnon.levi@ars. usda.gov.
DNA samples were isolated from these resistant $F_{2}$ plants and were tested with the two CAPS markers and the ZYRP-SCAR marker associated with ZYMV-FL resistance mentioned previously. In contrast with ZYMV-susceptible control plants, including 'Charleston Gray' and 'Desert King', that were homozygous for the susceptible eIF4E allele or susceptible $F_{2}$ plants that were homozygous or heterozygous for the susceptible eIF4E allele, the ZYMVresistant plants were all homozygous for the eIF4E allele derived from PI 595203 (as shown in Fig. 2). Each of the resistant $\mathrm{F}_{2}$ plants was self-pollinated to produce an $\mathrm{F}_{3}$ family. Resistance to ZYMV was confirmed in homozygous resistant $F_{3}$ families, and an $F_{3}$ plant that showed no virus symptoms and no virus presence in an ELISA test and was confirmed to be homozygous for the and no virus presence in the ELISA test were selected for additional evaluation.

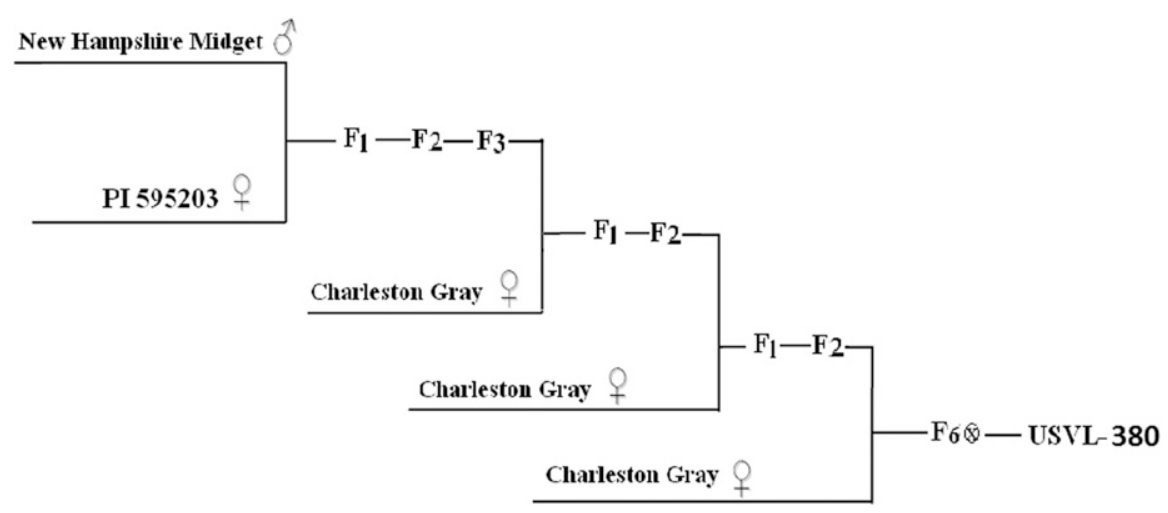

Fig. 1. Pedigree of USVL-380 showing the route of incorporating the Zucchini yellow mosaic virus resistance gene locus into the genome of the watermelon cultivar Charleston Gray (Citrullus lanatus var. lanatus).

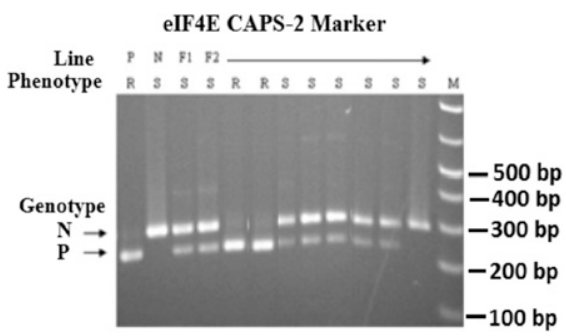

Fig. 2. Genotyping of plants throughout the breeding process of USVL-380 using the CAPS-2 marker for the eIF4E allele. Genotyping of CAPS-2 was performed using the primer pair KL08-03, 5' -AAAGCTACACCCACGGAAGA and KL08-04, 5' -CTCCAGAACTCCTCGACAGTAG and by digestion of their polymerase chain reactions amplicon with restriction enzyme Pas I (as described by Harris et al., 2009; Ling et al., 2009). From left to right, lanes 1 (P) is the Zucchini yellow mosaic virus (ZYMV)resistant PI 595203 parent (211 bp fragment). Lane $2(\mathrm{~N})$ is the susceptible watermelon cultivar Charleston Gray (268 bp fragment). Lane 3 is the F1 hybrid derived from crossing PI 595203 and 'New Hampshire Midget'. Lanes 4-12 are susceptible (S) and resistant (R) F2 progeny. The R progeny are homozygous for the eIF4E allele (211 bp fragment) derived from the ZYMV-resistant PI 595203, whereas the ZYMV-S plants are heterozygous for the eIF4E allele, or homozygous for the eIF4E allele derived from the parent cultivar.
Table 1. Virus disease severity (mean and sD) for plants of the Zucchini yellow mosaic virus (ZYMV)-susceptible watermelon cultivars Charleston Gray and Desert King, the ZYMV-resistant PI 595203, and USVL-380. ${ }^{\mathrm{z}}$

\begin{tabular}{lll}
\hline Accession & Mean & SEM \\
\hline USVL-380 & $1.1 \mathrm{a}$ & 0.0 \\
USVL-370 & $1.2 \mathrm{a}$ & 0.0 \\
PI 595203 & $1.0 \mathrm{a}$ & 0.0 \\
Charleston Gray & $3.6 \mathrm{~b}$ & 0.45 \\
Desert King & $3.6 \mathrm{~b}$ & 0.1 \\
\hline
\end{tabular}

${ }^{\mathrm{z}}$ Disease severity was evaluated 3 weeks after five blocks (randomized complete block design) in the greenhouse (day and night temperatures of 26 and $18{ }^{\circ} \mathrm{C}$, respectively) and evaluated for virus symptoms 3 weeks after inoculation. The rating system used healthy uninfected plants of watermelon cultivars as reference control to identify sick plants resulting from virus infection. Virus disease severity was rated as follows: 1) no symptoms, 2) slight mosaic on leaves, 3) mosaic patches and/or necrotic spots on leaves, or leaves near apical meristem are deformed, are yellow in color, and have reduced leaf size, 4) extensive mosaic appearance and leaf deformation and plant is stunted, 5) extensive mosaic appearance and severe leaf deformation and plant is entirely stunted or dead.

'Mean separation within columns by Fisher's protected least significant test, $P \leq 0.05$. the first inoculation: plants were randomized in 
Table 2. Watermelon fruit characteristics for USVL-380 and cultivars grown in a field of the U.S. Vegetable Laboratory, Charleston, SC, in the Summer of 2014. Mean $\pm(\mathrm{SEM})$.

\begin{tabular}{|c|c|c|c|c|c|c|c|c|c|}
\hline Accession & Shape & $\begin{array}{l}\text { Length } \\
(\mathrm{cm})\end{array}$ & $\begin{array}{l}\text { Width } \\
(\mathrm{cm})\end{array}$ & Wt $(\mathrm{kg})$ & $\begin{array}{l}\text { Number of } \\
\text { fruits }\end{array}$ & $\begin{array}{c}\text { Rind } \\
\text { thickness }\end{array}$ & $\begin{array}{l}\text { Rind } \\
\text { pattern }\end{array}$ & Flesh & Brix \\
\hline USVL-370 & Ovular & $30.51(1.60)^{z}$ & $24.71(0.81)$ & $9.14(1.01) \mathrm{a}$ & $1.4(0.02) \mathrm{a}$ & $2.51(0.17) \mathrm{a}$ & Light green gray & Light red & $8.6(0.35) \mathrm{a}$ \\
\hline Charleston Gray & Elongated & 48.04 (2.32) & $21.13(0.40)$ & $10.97(2.70) \mathrm{a}$ & $1.2(0.01) \mathrm{a}$ & $1.25(0.02) b$ & Light green gray & Light red & $10.9(0.29) \mathrm{b}$ \\
\hline Dixie-Lee & Ovular & 27.84 (1.95) & $24.16(1.78)$ & $11.60(1.41) \mathrm{a}$ & $2.3(0.08) \mathrm{a}$ & $1.90(0.06) \mathrm{ab}$ & $\begin{array}{c}\text { Dark green stripes } \\
\text { on a light green } \\
\text { background }\end{array}$ & Red & $9.9(0.45) \mathrm{ab}$ \\
\hline
\end{tabular}

${ }^{\mathrm{z}}$ Data were collected from four plots (three plants in each plot, with a distance of $3 \mathrm{ft}$ between them) arranged in a randomized complete block design with $9 \mathrm{ft}$ between plots. Data are presented as Mean \pm (SEM).

${ }^{\mathrm{y}}$ Mean separation within columns by Fisher's protected least significant test, $P \leq 0.05$.

Table 3. Watermelon fruit characteristics for USVL-380 and cultivars grown in a field of the U.S. Vegetable Laboratory, Charleston, SC, in the Summer of 2015. Mean $\pm(\mathrm{SEM})$.

\begin{tabular}{|c|c|c|c|c|c|c|c|c|c|}
\hline Accession & Shape & $\begin{array}{l}\text { Length } \\
(\mathrm{cm})\end{array}$ & $\begin{array}{l}\text { Width } \\
(\mathrm{cm})\end{array}$ & Wt $(\mathrm{kg})$ & $\begin{array}{c}\text { Number of } \\
\text { fruits }\end{array}$ & $\begin{array}{c}\text { Rind } \\
\text { thickness }\end{array}$ & $\begin{array}{l}\text { Rind } \\
\text { pattern }\end{array}$ & Flesh & Brix \\
\hline USVL-370 & Ovular & $29.02(1.24)$ & $23.98(0.88)$ & $9.14(1.01) \mathrm{ab}$ & $1.4(0.01) \mathrm{a}$ & $2.48(0.18)$ a & Light green gray & Light red & $8.7(0.60) \mathrm{a}$ \\
\hline Charleston Gray & Oblong & $44.56(2.34)$ & $19.36(0.64)$ & $9.42(0.78) a b$ & $1.1(0.02) \mathrm{a}$ & $1.48(0.22) b$ & Light green gray & Light red & $10.6(1.02) \mathrm{ab}$ \\
\hline Georgia Rattle Snack & Oblong & $37.24(2.84)$ & $18.70(0.56)$ & $6.95(0.62)$ a & $1.8(0.04) b$ & $1.78(0.28) \mathrm{ab}$ & $\begin{array}{l}\text { Dark green stripes } \\
\text { on a light green } \\
\text { background }\end{array}$ & Red & $9.2(0.59) \mathrm{ab}$ \\
\hline
\end{tabular}

${ }^{\mathrm{z}}$ Data were collected from four plots (three plants in each plot, with a distance of $3 \mathrm{ft}$ between them) arranged in a randomized complete block design with $9 \mathrm{ft}$ between plots. Data are presented as Mean \pm (SEM).

${ }^{\mathrm{y}}$ Mean separation within columns by Fisher's protected least significant test, $P \leq 0.05$.

eIF4E allele derived from PI 595203 (Fig. 2) was selected and crossed to 'Charleston Gray'.

Ten $F_{1}$ plants derived from this cross were genotyped, and a plant that was confirmed to have the eIF4E allele of PI 595203 was selfpollinated to produce $\mathrm{F}_{2}$ seeds. Thirty young $\mathrm{F}_{2}$ plants were tested for ZYMV resistance, and a plant that showed no ZYMV symptoms and no virus presence in an ELISA test and was homozygous for the PI 595203 eIF4E allele was selected and backcrossed with 'Charleston Gray' to produce $\mathrm{BC}_{1}$ plants. A $\mathrm{BC}_{1}$ plant that contained the PI 595203 eIF4E allele was self-pollinated to produce $\mathrm{BC}_{1} \mathrm{~F}_{2}$ seeds (Fig. 1). As described in the previous stage, $30 \mathrm{BC}_{1} \mathrm{~F}_{2}$ plants were evaluated, and a plant that showed no ZYMV symptoms and no virus presence in the ELISA test and was homozygous for the PI 595203 eIF4E allele was selected and further backcrossed with 'Charleston Gray' to produce $\mathrm{BC}_{2}$ seeds. The selection process was further advanced to produce $\mathrm{BC}_{2} \mathrm{~F}_{2}$ seeds, and a resistant $\mathrm{BC}_{2} \mathrm{~F}_{2}$ plant was selected and advanced through the aforementioned selection criteria in four generations to produce $\mathrm{BC}_{2} \mathrm{~F}_{7}$ resistant plants, designated as USVL-380.

In greenhouse tests at the U.S. Vegetable Laboratory (Charleston, SC) during 2013 and 2014, the USVL-380 plants showed significantly higher resistance to ZYMV compared with the heirloom watermelon cultivars Charleston Gray or Desert King that were used as susceptible controls (Table 1).

\section{Description}

USVL-380 is a sister line of USVL-370 and has the same breeding scheme for this

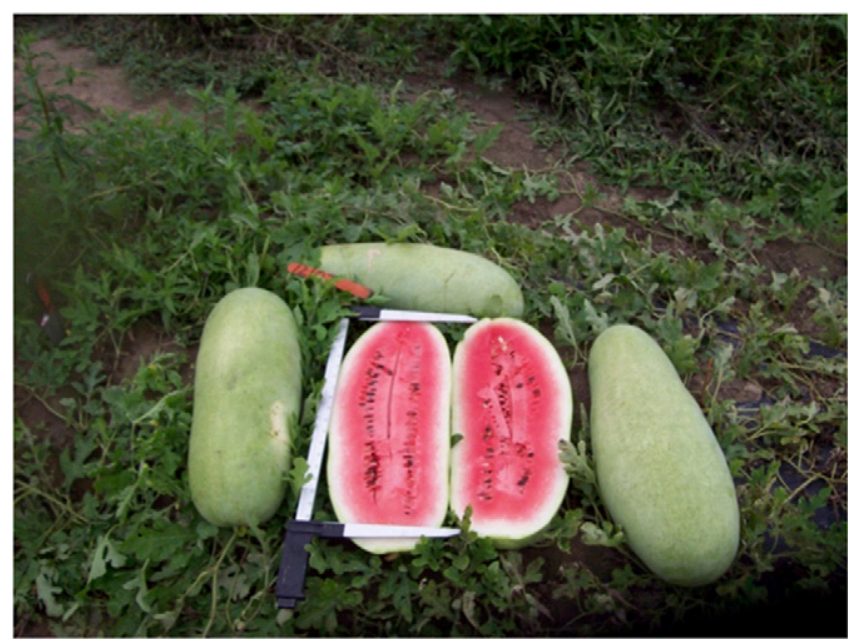

Fig. 3. USVL-380 fruits harvested in the field in Charleston, SC (Summer 2014).

ZYMV-resistant line (Levi et al., 2016). However, in contrast with the ovular watermelon fruit of USVL-370, USVL-380 has an elongated fruit, similar to the recurrent backcross parent 'Charleston Gray'. USVL-380 has a slightly thick rind, similar to USVL-370 (rind thickness is $2.2-2.5 \mathrm{~cm}$ ) (Tables 2 and 3). In field trials in Charleston, SC (2014-15), USVL-380 plants produced on average 1.2 large mature fruits per plant (Tables 2 and 3; Figs. 3 and 4) in mid-late season (78-82 d post-planting), comparable with 'Charleston Gray' or 'Crimson Sweet'. The mature fruits of USVL-380 have light green-gray dappled rind, resembling that of 'Charleston Gray' (Fig. 4), and light red flesh color with a sweet flavor, but with a lower solid soluble content compared with traditional cultivars. The USVL-380 watermelon flesh is firm with a slightly crispy texture and does not exhibit hollow heart (Fig. 4). The fruit contains light brown seeds ( $7.0 \mathrm{~mm}$ long and $4 \mathrm{~mm}$ width). USVL-380 should be useful in breeding programs aiming to enhance resistance to potyviruses in watermelon cultivars.

\section{Seed Availability}

Small samples of seed of USVL-380 are available for distribution to interested research personnel and plant breeders who make written request to Drs. Amnon Levi 

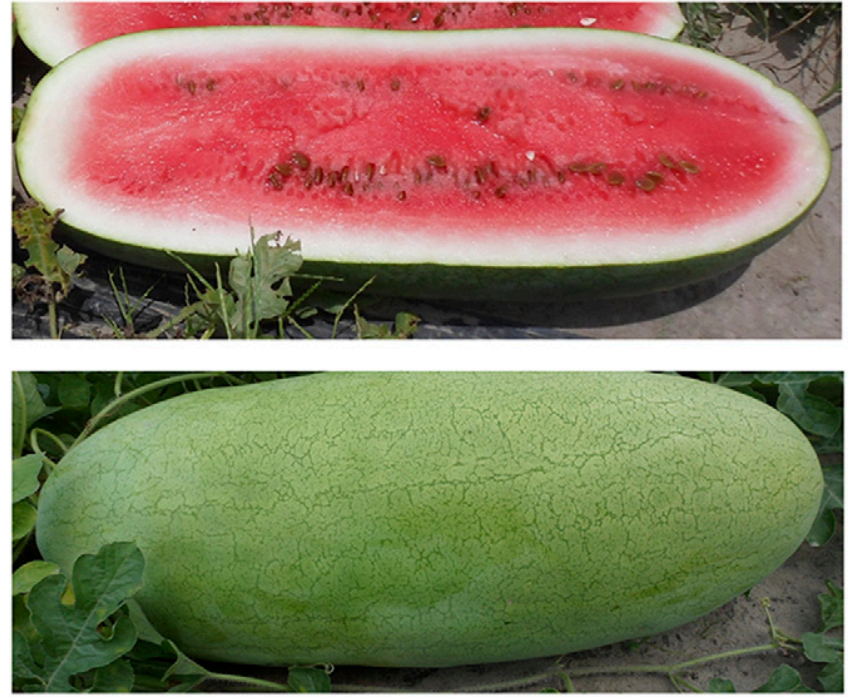

Fig. 4. USVL-380 fruits harvested in the field in Charleston, SC (Summer 2015).

or Kai-shu Ling, U.S. Vegetable Laboratory, 2700 Savannah Highway, Charleston, SC 29414-5334. Seed of USVL-380 will also be submitted to the National Plant Germplasm System where it will be available for research purposes, including the

new cultivars. line or cultivar.

\section{Literature Cited}

Guner, N. 2004. Papaya ringspot virus watermelon strain and Zucchini yellow mosaic virus resistance in watermelon. Dept. Hort. Sci., North Carolina State Univ., Raleigh, $\mathrm{PhD}$ Diss.

Harris, K.R., K.S. Ling, W.P. Wechter, and A. Levi. 2009. Identification and utility of markers linked to the Zucchini yellow mosaic virus resistance gene in watermelon. J. Amer. Soc. Hort. Sci. 134:529-534.

Levi, A., R.K. Harris-Shultz, and K. Ling. 2016. USVL-370, a Zucchini yellow mosaic virusresistant Watermelon Breeding Line. HortScience 51:107-109.

Ling, K.S., K.R. Harris, J.D.F. Meyer, A. Levi, N. Guner, T.C. Wehner, A. Bendahmane, and M.J. Havey. 2009. Non-synonymous single nucleotide polymorphisms in the watermelon eIF4E gene are closely associated with resistance to Zucchini yellow mosaic virus. Theor. Appl. Genet. 120:191-200.

Provvidenti, R., D. Gonsalves, and H.S. Humaydan. 1984. Occurrence of Zucchini yellow mosaic virus in cucurbits from Connecticut, New York, Florida, and California. Plant Dis. 68:443-446. priate recognition of the source be given when this germplasm contributes to research or development of a new breeding

Provvidenti, R. 1991. Inheritance of resistance to the Florida strain of Zucchini yellow mosaic virus in watermelon. HortScience 26:407-408. 